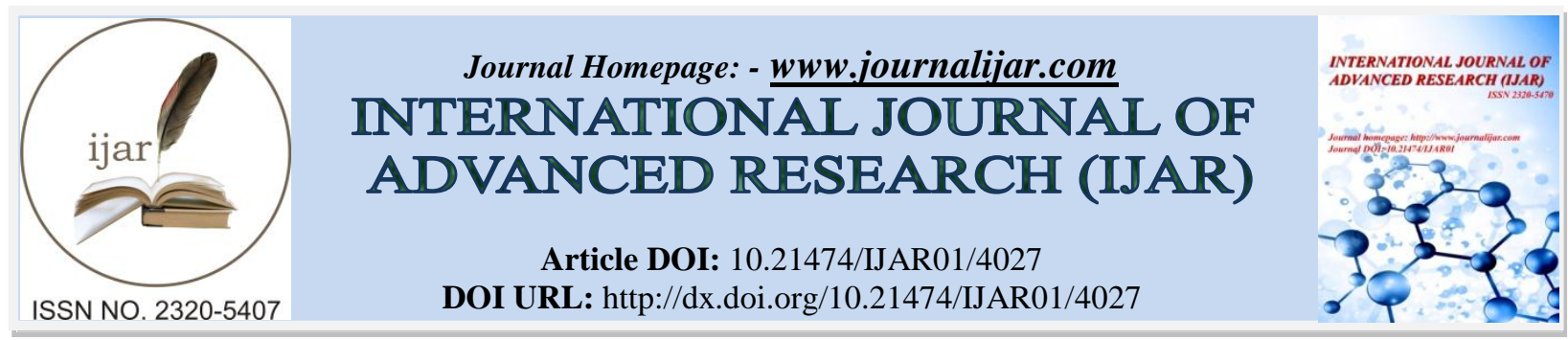

RESEARCH ARTICLE

\title{
EVALUATION OF YKL-40 AS A PROGNOSTIC MARKER IN ADULT ACUTE MYELOID LEUKEMIA PATIENTS.
}

Mohamed Eissa ${ }^{1,2}$ and Amal Ahmad Zidan ${ }^{1}$.

1. Clinical Pathology Department, Faculty of Medicine, Zagazig University

2. Pathology Department College of Medicine, King Khalid University

\section{Manuscript Info}

Manuscript History

Received: 26 February 2017

Final Accepted: 20 March 2017

Published: April 2017

\begin{abstract}
Acute myeloid leukemia (AML) is a clonal hematopoietic stem cell disorder, characterized by arrested differentiation, inappropriate proliferation and survival of immature myeloid progenitors. The AML has the low survival rate. So, assessment of the prognostic factors in AML is very important.

We aimed in this study to assess whether YKL-40 serum levels could be considered as a useful biomarker for the assessment of disease status progression and monitoring the response to treatment in patients with AML.

Forty eight subjects were included in this study. They were classified into 2 groups; 24 apparently healthy adult subjects and 24 adult patients with newly diagnosed AML. Both groups were subjected to routine laboratory investigations and Estimation serum YKL-40 level by ELISA.

There was a significant difference between levels of YKL-40 in control and patient group before induction therap. There was also a significant difference between YKL-40 level and the response to treatment and between its level and outcome during follow up period in responder patient group. Finally, by using Kaplan Meier curve; median time of DFS was significantly shorter in patients with YKL-40 $\geq 137 \mathrm{ng} / \mathrm{ml}$ compared to those with YKL-40 $<137 \mathrm{ng} / \mathrm{ml}$.

It can be concluded that high serum level of YKL-40 was associated with bad response to treatment and confers poor outcome. Moreover, it could serve as valuable prognostic marker.
\end{abstract}

Copy Right, IJAR, 2017,. All rights reserved.

\section{Introduction:-}

Acute myeloid leukemia (AML) is a malignant disorder of the blood characterized by impaired differentiation of hematopoietic precursor cells, resulting in abnormal accumulation of immature precursors and suppression of growth and maturation of cells involved in normal hematopoiesis. (1)

The prognosis for AML patients is very variable, ranging from survival of a few days to cure. Clinical outcome can be partly predicted by age, cytogenetic findings, and serum lactate dehydrogenase at the time of diagnosis. $(2,3)$

YKL-40 is an inflammatory glycoprotein associated with mammalian chitanase-like proteins (CHI3L1). It is expressed and oozed by some types of solid tumor cells, inflammatory cells and stem cells. The plasma/serum YKL- 
40 level is often elevated in patients with disease depicted by inflammation, like some types of infections compared to normal healthy volunteers. $(4,5)$

It has been suggested that it plays a role in differentiation, overgrowth of cancer cell, cell attachment, metastatic potential, cell migration, tissue remodeling and tissue reorganization. $(6,7,8)$

In normal bone marrow, the myelocyte-metamyelocyte expresses YKL-40 protein and it is stored in the specific granules of neutrophil granulocytes and released from fully activated cells. (9)

It is located on chromosome 1q32.1. Two splice forms of the YKL-40 gene are reported; isoform 1 that contains exon 1-10 and isoform 2, where exon 8 is spliced out. (10)

Several clinical analysis of patients with distinct types of cancer revealed that the higher concentration of YKL-40 in serum also seems to correlate with poor prognosis and short survival in some types of cancers including ovary, breast, glioblastoma melanoma and colorectal cancer. $(11,12,13,14,15)$

YKL-40 protein expression has not been evaluated in tissue from patients with leukemia and lymphoma. In myeloma, YKL-40 arises from cells in the bone marrow microenvironment surrounding the myeloma cells. (16)

Over expression of plasmaYKL-40 was frequently noticed in patients with leukemia. High-expression of YKL-40 protein in leukemic patients may promote tumorigenesis or cancer progression and the plasma level of YKL-40 was elevated through increasing extracellular matrix degradation. (17)

Therefore it is important to identify new biomarkers in AML patients for the prediction of prognosis and treatment response, detection of relapse, and monitoring for minimal residual disease of AML.

\section{Aim:-}

The aim of this study is to assess whether serum levels of YKL-40 could be considered as a useful biomarker for the assessment of disease status progression and monitoring the response to treatment in patients with AML.

\section{Subjects and Methods:-}

This study was carried out at Clinical Pathology and Medical Oncology \& Hematology Departments, Faculty of Medicine, Zagazig University Hospitals.

Forty eight subjects were included in this study. They were classified into 2 groups:

$>$ Control group: It Included 24 apparently healthy adult subjects. They were 12 males and 12 females. Their ages ranged from 18-65 years with a mean age of 35.8 \pm 13.5 years. They matched well with patients as regard age and sex.

> Patient group: It Included 24 adult patients with newly diagnosed denovo AML. They were 10 males and 14 females. Their ages ranged from 19-65 years with a mean age of $38 \pm 16.2$ years.

\section{Patient Inclusion criteria:-}

Patients newly diagnosed as AML admitted to Medical Oncology Department in Zagazig University Hospitals.

\section{Patient Exclusion criteria:-}

1. Patients with inflammatory conditions.

2. Patients with severe infections.

3. Patients with other malignancy.

4. Patients with cardiovascular condition and diabetic patients.

\section{Each group was subjected to the following:-}

Control group:-

Routine laboratory investigations:

- Complete blood count and blood smear examination.

- Liver, kidney function tests and lactate dehydrogenase. 


\section{Estimation of YKL-40 level by ELISA. \\ Patient group:-}

1. Complete history taking.

2. Clinical examination was done particularly for fever, purpura, bruising, gum swelling, lymphadenopathy, organomegally and CNS manifestation.

3. Routine laboratory invistgations:

- Complete blood picture and blood smear examination.

- Liver, kideny function tests and lactate dehydrogenase.

4. Bone marrow aspiration and examination followed by cytochemistry and immunophenotyping.

5. Cytogenetic examination.

6. Estimation of YKL-40 level by ELISA, at the onset of the disease and after 1 month of induction treatment.

\section{Treatment:-}

Patients were treated by an induction regimen $3 \& 7$ regimen consisting of continuous infusion cytarabine $\left(100 \mathrm{mg} / \mathrm{m}^{2}\right)$ daily for 7 consecutive days combined with 3 days of doxorubicin $\left(30 \mathrm{mg} / \mathrm{m}^{2}\right)$. Patients with 60 years or poor performance status were treated by $2 \& 5$ (cytarabine $100 \mathrm{mg} / \mathrm{m}^{2}$ daily for 5 combined with 3 days of doxorubicin $25 \mathrm{mg} / \mathrm{m}^{2}$ ) regimen low dose cytarabine $10 \mathrm{mg} / \mathrm{m}^{2} / 12$ hours for 14 days.

\section{Patients follow up:-}

- After 1 month; patients are reevaluated for assessment the initial response of treatment.

- Complete remission (CR):A bone marrow with normal hematopoiesis of all cell lines, $<5 \%$ blast cells, and peripheral blood with at least $1.5 \times 10^{9} / \mathrm{L}$ neutrophils and $\geq 100 \times 10^{9} / \mathrm{L}$ platelets.

- Partial remission (PR): Presence of BM blast cells 5-20\%.

- No remission (NR):

1. Induction death, related to treatment and or hypoplasia.

2. Resistance disease, related to failure of therapy to eliminate the disease.

- Patients who had CR followed up for 1 year to assess its outcome and disease free survival (DFS).

\section{Specimen Collection:-}

1. Three $\mathrm{mL}$ of venous blood sample was aseptically withdrawn from each subject by venipuncture.

2. Another sample was collected from group II only after 1 month of induction treatment.

- The blood sample was delivered into sterile plain vacutainer tube with stopper, left to clot at $37^{\circ} \mathrm{C}$ for 10 minutes, and then centrifuged at $3000 \mathrm{rpm}$ for 10 minutes. Part of serum was used for liver, kidney functions and LDH estimation and the other part of serum was stored at $-80^{\circ} \mathrm{C}$ for YKL-40 level estimation by ELISA.

3. Bone marrow samples were aspirated from patients under complete aseptic conditions. Bone marrow smears were prepared and bone marrow samples were delivered into EDTA vacutainer tube for immunophenotyping by flowcytometry.

\section{Estimation of serum YKL-40:- Principle:-}

YKL-40 level estimation by ELISA using Human Chitinase 3-Like 1/ YKL-40 PicoKineTM ELISA Kit California USA. This assay employs standard sandwich enzyme-linked immune-sorbent assay technology. A monoclonal antibody from mouse specific for Chitinase 3-like 1 has been precoated onto 96-wellplates. Standards (NSO, Y22T383) and test samples are added to the wells, a biotinylated detection polyclonal antibody from goat specific for Chitinase 3-like 1 is added subsequently and then followed by washing with PBS or TBS buffer. Avidin-BiotinPeroxidase complex was added and unbound conjugates were washed away with PBS buffer. HRP substrate TMB was used to visualize HRP enzymatic reaction. TMB was catalyzed by HRP to produce a blue color product that changed into yellow after adding acidic stop solution. The density of yellow is proportional to the human Chitinase 3-like 1 amount of sample captured in plate.

\footnotetext{
Reagents:-

1. 96well plate precoated with anti- human Chitinase 3-likeantibody.

2. Lyophilized recombinant human Chitinase 3 -like 1 standard.

3. Biotinylated anti- human Chitinase 3-like 1 antibody.

4. Avidin-Biotin-Peroxidase Complex (ABC).
} 
5. Sample diluent buffer.

6. Antibody diluent buffer.

7. $\mathrm{ABC}$ diluent buffer.

8. TMB color developing agent.

9. TMB stop solution.

\section{Sample preparation:-}

It was diluted in 1:10 with the sample diluent buffer and mixed thoroughly. Twenty five $\mu l$ of sample was added to $225 \mu \mathrm{l}$ of sample diluent buffer.

\section{Reagent preparation:-}

Reconstitution of the human Chitinase 3-like 1 standard: Chitinase 3-like 1 standard solution was prepared no more than 2 hours prior to the experiment. Two tubes of Chitinase 3-like 1 standard (10 ng per tube) were included in each kit.

1. $10,000 \mathrm{pg} / \mathrm{ml}$ of human Chitinase 3-like 1 standard solution: $1 \mathrm{ml}$ sample diluent buffer was added into one tube; the tube was kept at room temperature for $10 \mathrm{~min}$ and mixed thoroughly.

2. $4000 \mathrm{pg} / \mathrm{ml}$ of human Chitinase 3-like 1 standard solution: $0.4 \mathrm{ml}$ of the above 10,000 pg/ml Chitinase 3-like 1 standard solution was added into $0.6 \mathrm{ml}$ sample diluent buffer and mixed thoroughly.

3. $2000 \mathrm{pg} / \mathrm{ml} \rightarrow 62.5 \mathrm{pg} / \mathrm{ml}$ of human Chitinase 3-like 1 standard solutions:

Six eppendorf tubes were labeled with $2000 \mathrm{pg} / \mathrm{ml}, 1000 \mathrm{pg} / \mathrm{ml}, 500 \mathrm{pg} / \mathrm{ml}, 250 \mathrm{pg} / \mathrm{ml}, 125 \mathrm{pg} / \mathrm{ml}, 62.5 \mathrm{pg} / \mathrm{ml}$; respectively. Three hundred $\mu 1$ of the sample diluent buffer was added into each tube. $300 \mu 1$ of the above 4000 $\mathrm{pg} / \mathrm{ml}$ Chitinase 3-like 1 standard solution was added into 1 st tube and mixed. $300 \mu \mathrm{l}$ from 1st tube was transferred to 2 nd tube and mixed. $300 \mu \mathrm{l}$ from 2 nd tube was transferred to 3 rd tube and mixed, and so on.

Preparation of biotinylated anti-human Chitinase 3-like 1 antibody working solution:

The solution was prepared no more than 2 hours prior to the experiment.

1. The total volume was: $0.1 \mathrm{ml} /$ well $\mathrm{x}$ (the number of wells).

2. Biotinylated anti-human Chitinase 3-like 1 antibody was diluted in 1:100 with the antibody diluent buffer and mixed thoroughly.

\section{Preparation of Avidin-Biotin-Peroxidase Complex (ABC) working solution:-}

The solution was prepared no more than 1 hour prior to the experiment.

1. The total volume was: $0.1 \mathrm{ml} /$ well $\mathrm{x}$ (the number of wells).

2. Avidin- Biotin-Peroxidase Complex (ABC) was diluted in 1:100 with the $\mathrm{ABC}$ dilution buffer and mixed thoroughly.

\section{Procedure:-}

1. One hundred $\mu 1$ of the $10,000 \mathrm{pg} / \mathrm{ml}, 4000 \mathrm{pg} / \mathrm{ml}, 2000 \mathrm{pg} / \mathrm{ml}, 1000 \mathrm{pg} / \mathrm{ml}, 500 \mathrm{pg} / \mathrm{ml}, 250 \mathrm{pg} / \mathrm{ml}, 125 \mathrm{pg} / \mathrm{ml}$ and $62.5 \mathrm{pg} / \mathrm{ml}$ human Chitinase 3-like 1 standard solutions were added into the precoated wells, one hundred $\mu 1$ of the sample diluent buffer was added to the control (Zero well).

2. One hundred $\mu 1$ of each properly diluted sample of serum was added to the well.

3. The plate was sealed with the cover and incubated at $37^{\circ} \mathrm{C}$ for $90 \mathrm{~min}$.

4. The cover was removed, plate content was discarded, and the plate was blotted onto paper towels.

5. One hundred $\mu 1$ of biotinylated anti-human Chitinase 3-like1 antibody working solution was added to each well and the plate was incubated at $37^{\circ} \mathrm{C}$ for $60 \mathrm{~min}$.

6. The plate was washed 3 times with PBS, and each time washing buffer stayed in the wells for 1-2 min. The washing buffer was discarded and the plate was blotted onto paper towels.

7. One hundred $\mu 1$ of prepared $\mathrm{ABC}$ working solution was added to each well and the plate was incubated at $37^{\circ} \mathrm{C}$ for $30 \mathrm{~min}$.

8. The plate was washed 5 times with PBS as in step 6.

9. Ninety hundred $\mu \mathrm{l}$ of prepared TMB color developing agent was added into each well. The plate was incubated at $37^{\circ} \mathrm{C}$ in dark for $30 \mathrm{~min}$.

10. One hundred $\mu 1$ of prepared TMB stop solution was added into each well. The color changes into yellow immediately.

11. The plate was read at $450 \mathrm{~nm}$ in a microplate reader within $30 \mathrm{~min}$. after the stop solution was added. 


\section{Generation of Standard Curve and Interpretation of Data:-}

A standard curve was constructed by plotting the mean absorbance for each standard on the y-axis against the concentration on the $\mathrm{x}$-axis on $\log$-log graph and a best fit line was drawn through the points on the graph. The human Chitinase 3-like1 concentration of the samples interpolated from the standard curve.

The data were tabulated and statistically analyzed using and SPSS version-20 software package.

\section{Descriptive statistics:-}

Data were summarized using the mean, standard deviation (SD), median and range for numerical variables. The frequency, distribution and percentage were calculated for categorized variables.

\section{Comparative Statistics:-}

The Following methods were used:-

$>$ Chi-square $\mathbf{X}^{2}$ test: It was used for comparing categorical variables to test whether the proportions across a number of categories of two or more independent groups is the same, where the null hypothesis is that they are.

$>$ Mann-Whitney test: a hypothesis test for non-parametric data, used to test whether or not the difference between two independent populations medians is zero, where the null hypothesis is that it is.

$>$ Independent " $t$ " test: used to test whether or not the difference between two independent population means is zero, where the null hypothesis is that it is

$>$ Krusskall-Wallis test: For comparing medians of more than three groups.

$>$ Correlation coefficient (r): It measures the closeness of the association between two quantitative continuous variables. This association is measured by the correlation coefficient.

$>$ Paired Wilcoxon test: The Wilcoxon test is the non-parametric equivalent of the paired samples t-test (sample data are not normally distributed and can't be transformed to a normal distribution by means of logarithmic transformation).

$>$ Diagnostic sensitivity, diagnostic specificity and receiver operating characteristics (ROC) curves and area under the ROC curve (AUC): were computed and cut-off values were chosen. The positive predictive value (PPV) and negative predictive value (NPV) were calculated as follows:

Diagnostic sensitivity: It measures the incidence of true positive results in patients group.

Diagnostic specificity: It measures the incidence of true negative results in a non-diseased group.

Positive predictive value: It is the percent of true positive results among all positive results.

Positive predictive value $=\mathrm{TP} /(\mathrm{TP}+\mathrm{FP}) \times 100$

Negative predictive value: It is the percent of true negative results among all negative results.

Negative predictive value $=\mathrm{TN} /(\mathrm{TN}+\mathrm{FN}) \times 100$

\section{Survival analysis:-}

Survival analysis was done according to Kaplan-Meier method (18), and compared by log-rank test (19). Differences were considered significant if $\mathrm{P}$ values were $\leq 0.05$.

This study included two groups: control group (24 normal individuals) and patient group (24 newly diagnosed de novo AML adult patients). The results statistically analyzed and came to the following:

\section{Results:-}

Table 1:- Comparison between YKL-40 levels in the two studied groups:

\begin{tabular}{|c|c|c|c|c|}
\hline Variable & $\begin{array}{l}\text { Patient group } \\
(n=24)\end{array}$ & $\begin{array}{l}\text { Control group } \\
(n=24)\end{array}$ & MW & $\mathbf{p}$ \\
\hline $\begin{array}{l}\text { YKL40 before ttt: } \\
\text { Mean } \pm \text { SD } \\
\text { Median } \\
\text { Range }\end{array}$ & $\begin{array}{l}202.46 \pm 156.45 \\
139 \\
28-623\end{array}$ & $\begin{array}{l}96.71 \pm 3.37 \\
98 \\
23-170\end{array}$ & 3.17 & $\begin{array}{l}\mathbf{0 . 0 0 2} \\
\mathrm{S}\end{array}$ \\
\hline $\begin{array}{l}\text { YKL40 after ttt : } \\
\text { Mean } \pm \text { SD } \\
\text { Median } \\
\text { Range }\end{array}$ & $\begin{array}{l}141 \pm 120.63 \\
98.5 \\
19-419\end{array}$ & 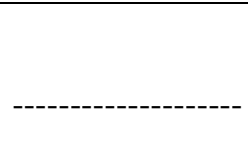 & -------- & ----------- \\
\hline Paired Wilicoxon & 4.23 & --------------------- & ---------- & ------------ \\
\hline
\end{tabular}




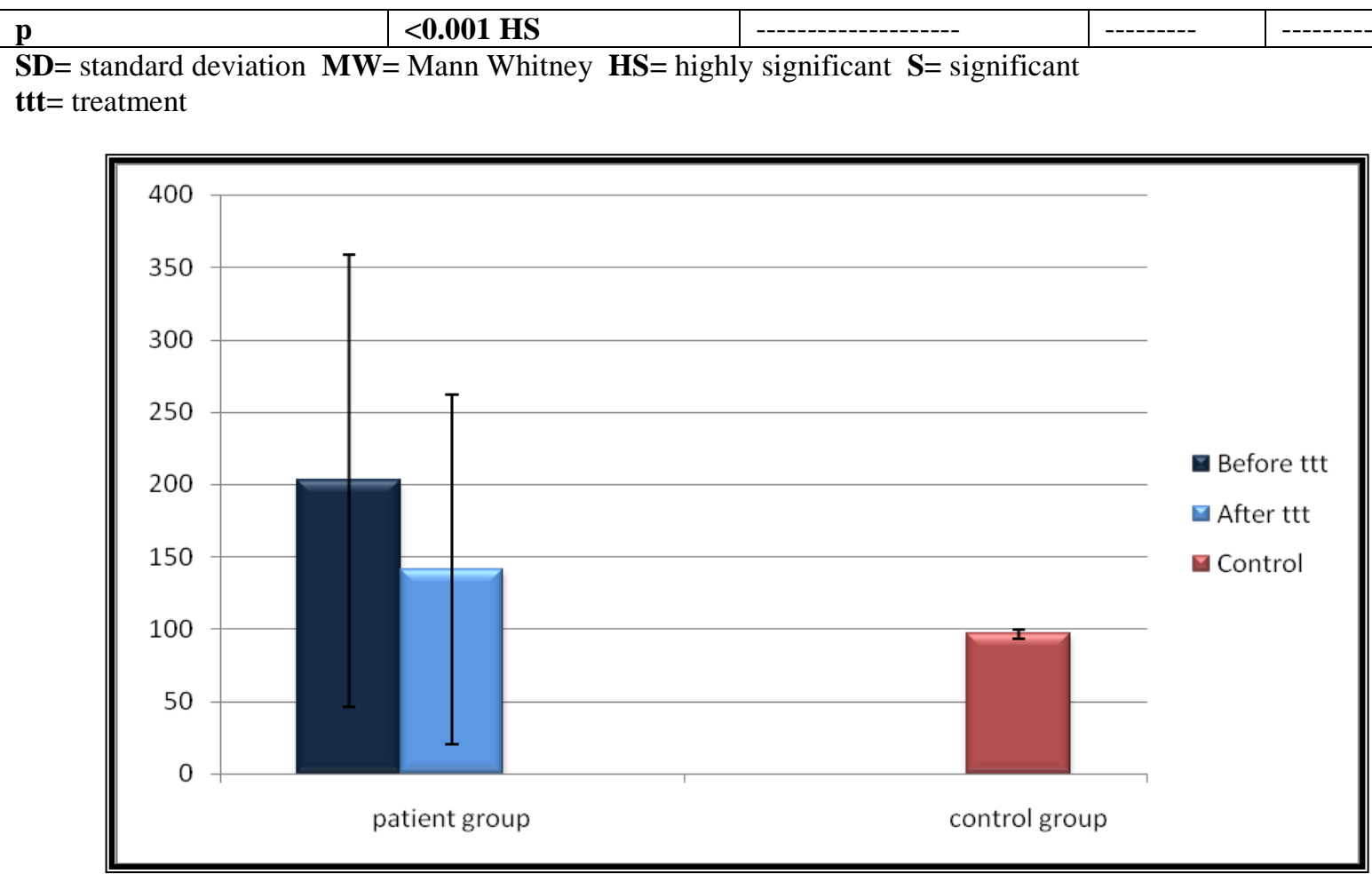

Fig. 1:- YKL 40 level in the two studied groups.

Table (1) and figure (1) show comparison between YKL-40 levels in two studied groups.

There was a significant difference between levels of YKL-40 in control and patient groups before the treatment $(\mathrm{P}=0.002)$. Moreover, there was a highly significant difference between patient groups before and after treatment $(\mathrm{P}<0.001)$.

Table 2:- Correlation between YKL 40 level and age and some laboratory findings in the patient group.

\begin{tabular}{|c|c|c|}
\hline \multirow[t]{2}{*}{ Variable } & \multicolumn{2}{|c|}{$\begin{array}{l}\text { YKL 40 } \\
(n=24)\end{array}$} \\
\hline & $\mathbf{r}$ & $\mathbf{P}$ \\
\hline Age (years) & 0.16 & 0.45 \\
\hline Hb (g/dl) & 0.05 & 0.81 \\
\hline TLC $\left(10^{9} / \mathrm{L}\right)$ & 0.49 & $0.02(\mathrm{~S})$ \\
\hline Platelets $\left(10^{9} / \mathrm{L}\right)$ & -0.83 & $<0.001(\mathrm{HS})$ \\
\hline LDH (IU/L) & 0.80 & $<0.001(\mathrm{HS})$ \\
\hline ESR (mm/hr.) & 0.22 & 0.31 \\
\hline BM blast (\%) & 0.18 & 0.40 \\
\hline Pb blast $(\%)$ & 0.04 & 0.87 \\
\hline
\end{tabular}

$\mathbf{r}=$ correlation coefficient $\quad \mathbf{S}=$ significant $\quad \mathbf{H S}=$ highly significant




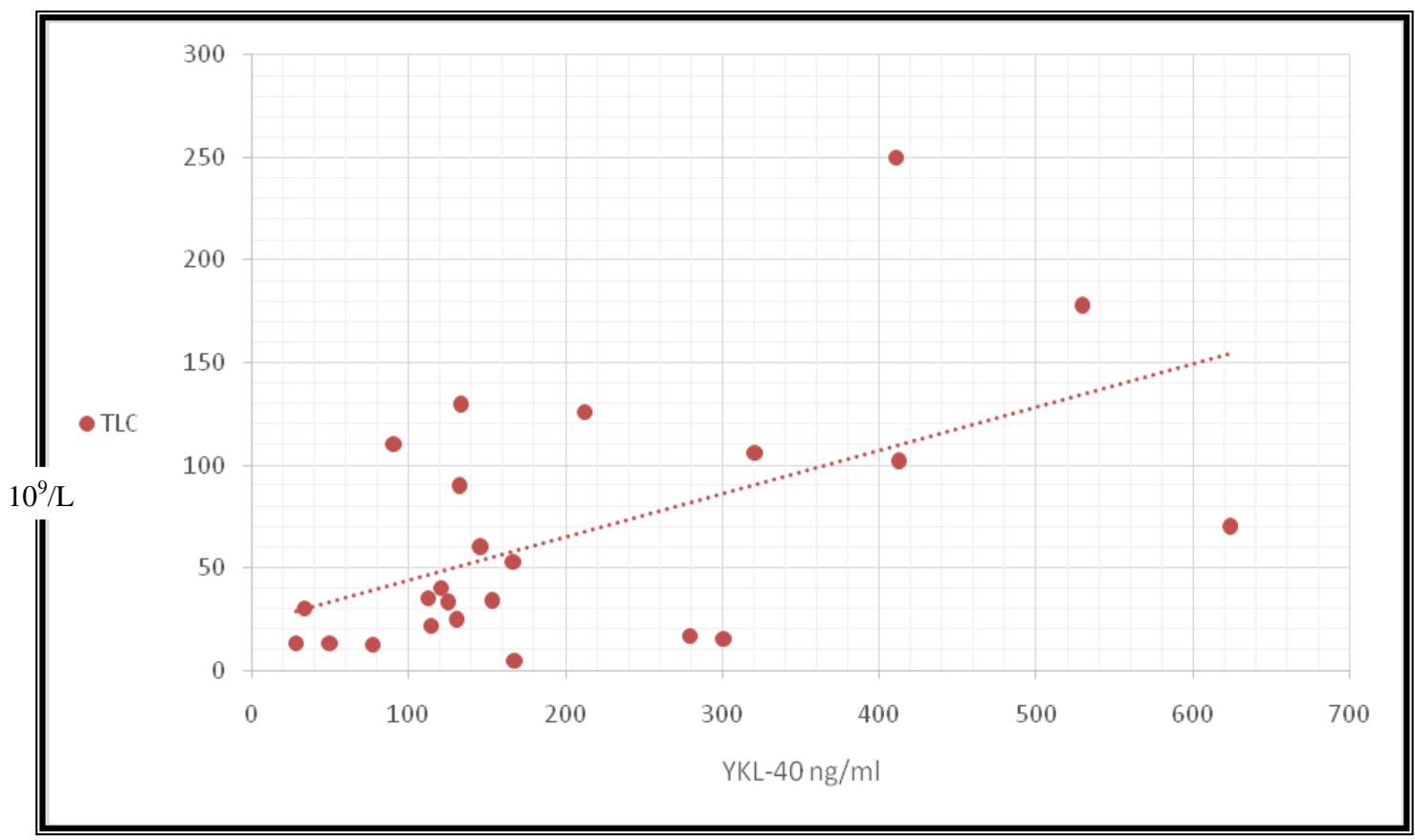

Fig. 2:- Correlation between YKL 40 level and TLC in the patient group.

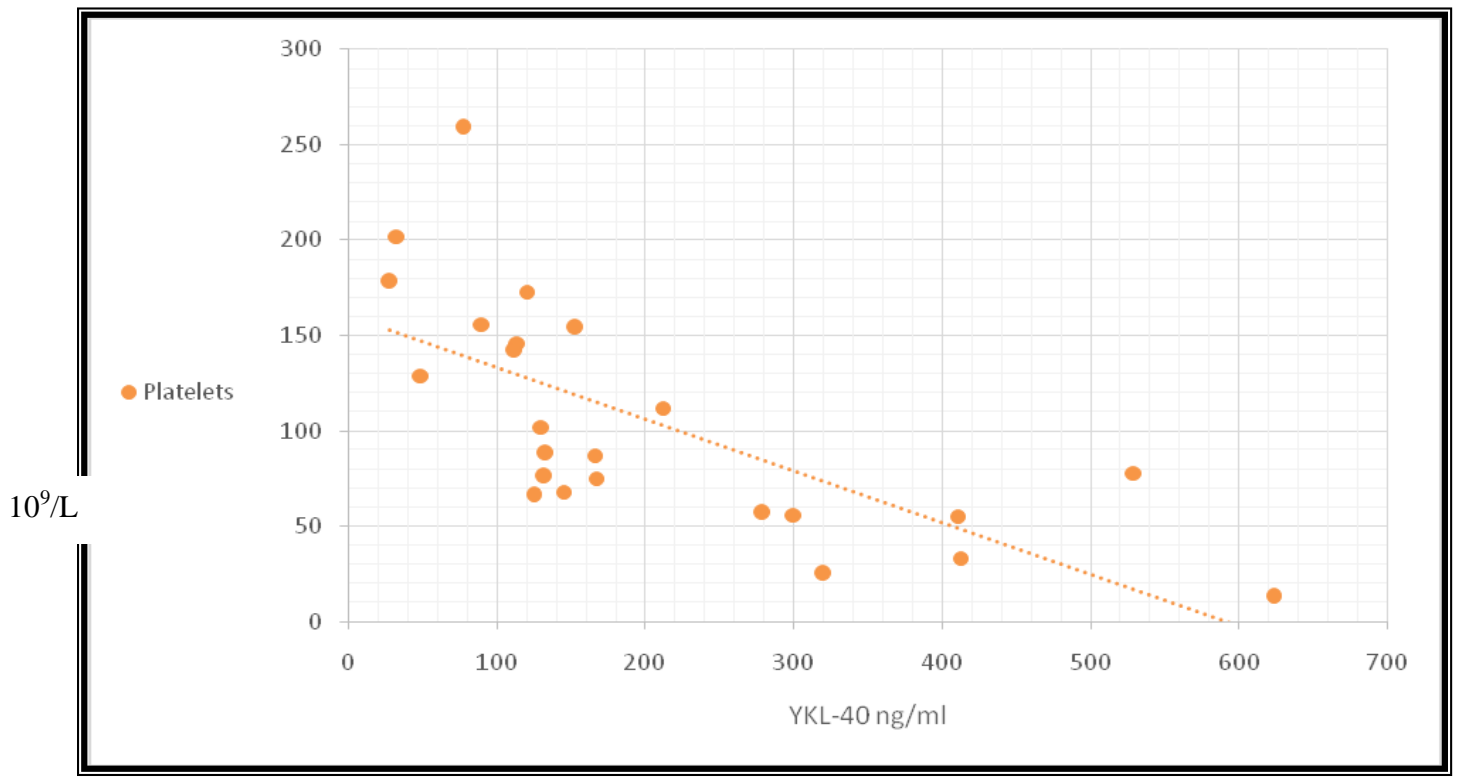

Fig. 3:- Correlation between YKL 40 level and platelets count in the patient group. 


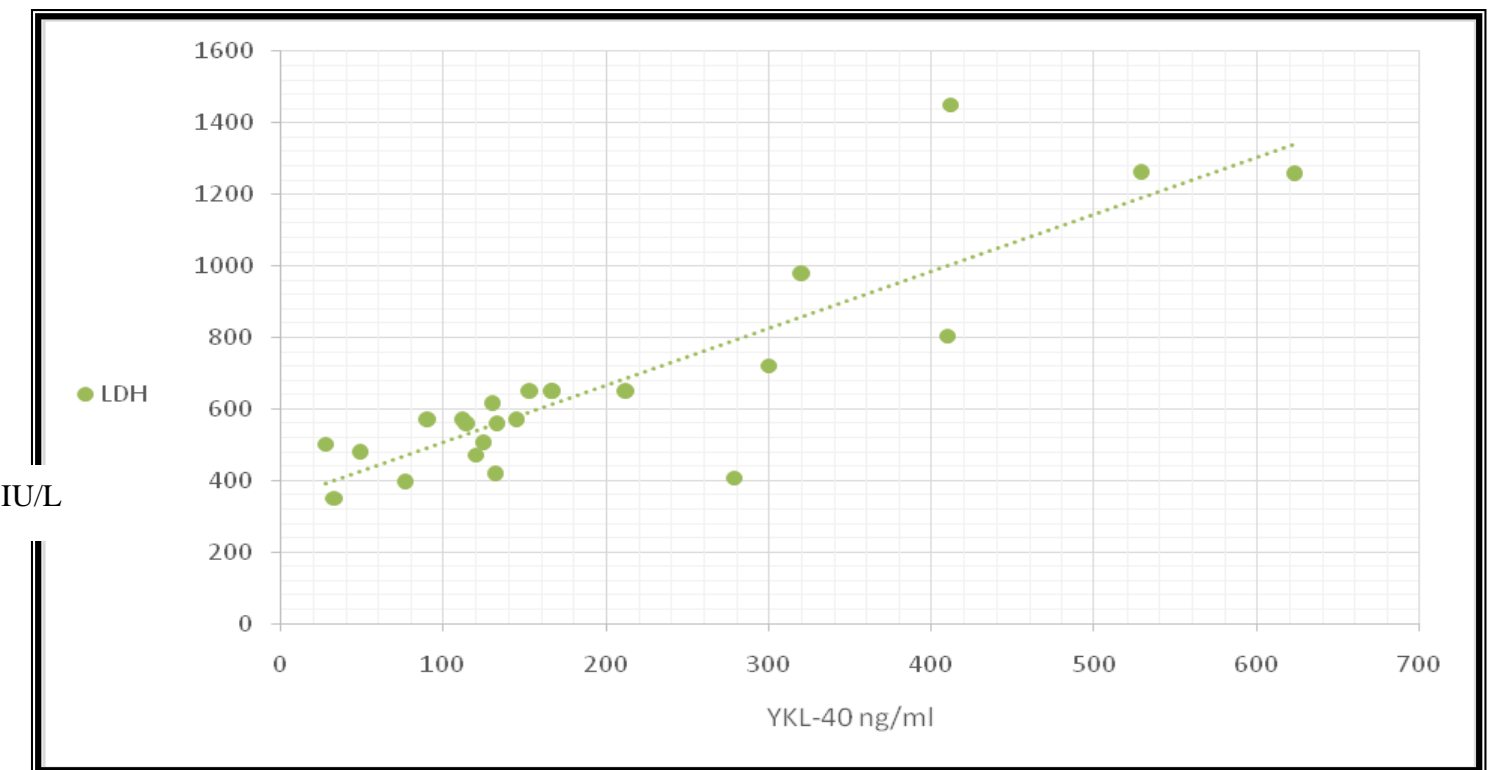

Fig. 4:- Correlation between YKL 40 level and LDH in the patient group.

Table (2) and figures (2, 3 and 4) show that there was a significant correlation between YKL-40 and TLC ( $\mathrm{P}=0.02)$, platelets $(\mathrm{P}<0.001)$ and LDH $(\mathrm{P}<0.001)$; while there were no significant correlation between YKL-40 and age, Hb, ESR, BM blast and $\mathrm{Pb}$ blast $(\mathrm{P}>0.05)$.

Table 3:- Validity of YKL-40 in prediction of response to treatment in the patient group.

\begin{tabular}{|l|l|l|l|l|l|l|l|l|}
\hline Cutoff & Sens. & Spec. & + PV & -PV & Accuracy & AUC & p-value & CI \\
\hline$\geq 137$ & 83.3 & 77.8 & 66.7 & 86.7 & 79.2 & 0.88 & $0.006(S)$ & $(0.73-1.03)$ \\
\hline
\end{tabular}

Sens.: sensitivity Sep.: specificity

AUC: Area under curve CI: confidence interval S: significant

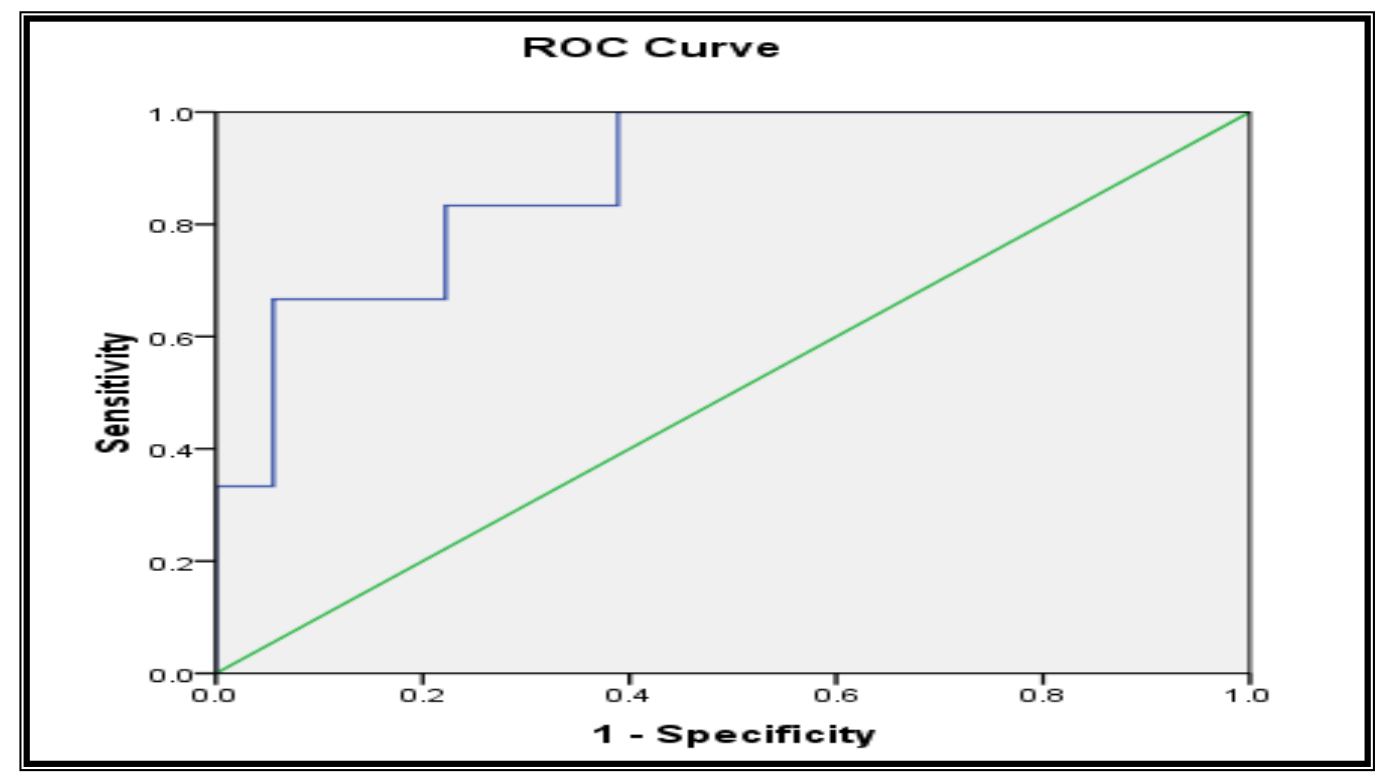

Fig. 5:- Roc curve of Validity of YKL 40 in prediction of response to treatment in the patient group.

Table (3) and figure (5) show that the cutoff value of YKL-40 for prediction of response to treatment in the patient group was $137 \mathrm{ng} / \mathrm{ml}$. The sensitivity was $83.3 \%$, specificity was $77.8 \%$, positive predictive value was $66.7 \%$, negative predictive value was $86.7 \%$ and area under curve was $0.88(\mathrm{P}<0.006)$. 
The patient group was reclassified according to cut-off value of YKL-40 level for prediction of response to treatment into two groups: patient group was with YKL-40 level $<137 \mathrm{ng} / \mathrm{ml}(\mathrm{n}=13)$ and the other was with YKL-40 $\geq 137$ $n g / m l(n=11)$.

Table 4:- Relation between level of YKL-40 and the response to treatment in the patient group.

\begin{tabular}{|c|c|c|c|c|c|c|}
\hline \multirow[t]{2}{*}{ Variable } & \multicolumn{2}{|c|}{$\begin{array}{l}<137 \mathrm{ng} / \mathrm{ml} \\
(n=13)\end{array}$} & \multicolumn{2}{|c|}{$\begin{array}{l}\geq 137 \mathrm{ng} / \mathrm{ml} \\
(\mathrm{n}=11)\end{array}$} & \multirow[t]{2}{*}{$\chi^{2}$} & \multirow[t]{2}{*}{$\mathbf{P}$} \\
\hline & No & $\%$ & No & $\%$ & & \\
\hline $\begin{array}{l}\text { Treatment response: } \\
\text { CR } \\
\text { NR }\end{array}$ & $\begin{array}{l}12 \\
1\end{array}$ & $\begin{array}{l}92.3 \\
7.7\end{array}$ & $\begin{array}{l}6 \\
5\end{array}$ & $\begin{array}{l}54.5 \\
45.5\end{array}$ & 4.53 & $0.03(S)$ \\
\hline $\begin{array}{l}\text { Follow up: } \\
\text { Remission } \\
\text { Relapsed }\end{array}$ & $\begin{array}{l}(\mathrm{n}=12) \\
11 \\
1\end{array}$ & $\begin{array}{l}91.7 \\
8.3\end{array}$ & $\begin{array}{l}(\mathrm{n}=6) \\
3 \\
3\end{array}$ & $\begin{array}{l}50 \\
50\end{array}$ & 5.12 & $0.02(S)$ \\
\hline
\end{tabular}

$\mathbf{C R}=$ complete remission $\mathbf{N R}=$ no remission $\chi^{2}=$ chi square $\mathbf{S}=$ significant

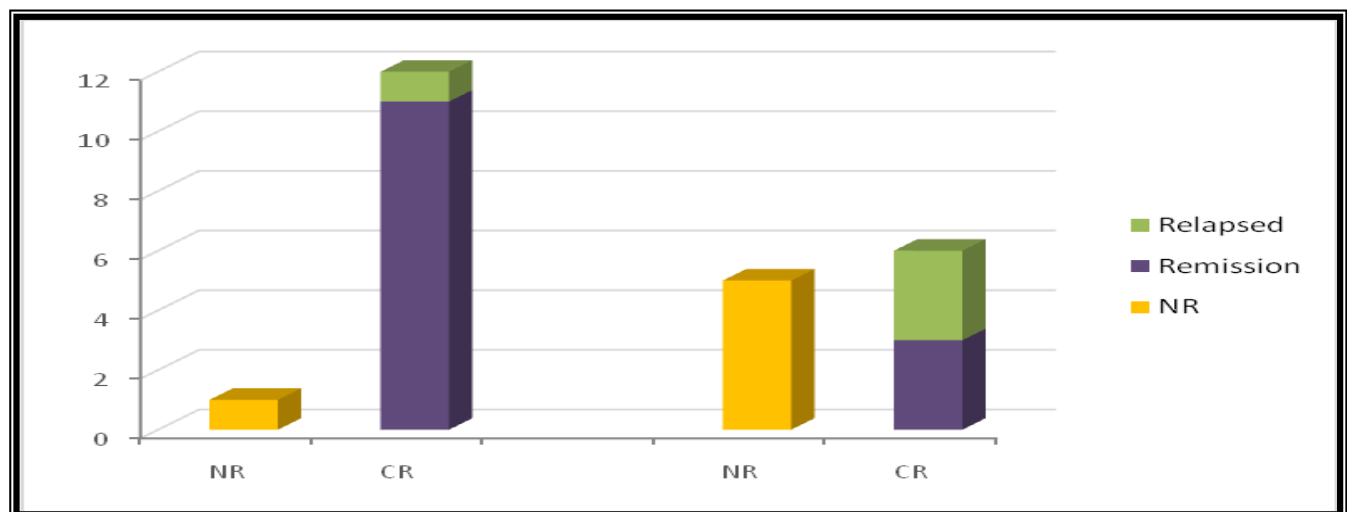

Fig. 6:- Relation between YKL-40 level and the response to treatment in the patient group.

Table (4) and (figure 6) show the relation between YKL-40 level and treatment response in the patient group. There was significant difference between YKL-40 level and the response to treatment $(\mathrm{P}=0.03)$ and between $\mathrm{YKL}-40$ level and outcome during follow up period in responder patient group $(\mathrm{P}=0.02)$.

Table 5:- Comparison between CR and NR groups as regard YKL-40 level.

\begin{tabular}{|l|l|l|l|l|}
\hline Variable & $\begin{array}{l}\text { CR group } \\
(\mathbf{n = 1 8})\end{array}$ & $\begin{array}{l}\text { NR group } \\
(\mathbf{n = 6})\end{array}$ & Test & $\mathbf{p}$ \\
\hline YKL 40 (ng/ml) : & $148.72 \pm 98.39$ & $363.67 \pm 195.21$ & $\mathbf{M W}$ & $\mathbf{0 . 0 0 4}$ \\
Mean \pm SD & 127.5 & 365 & $\mathbf{2 . 7 3}$ & $\mathbf{S}$ \\
Median & $28-412$ & $133-623$ & & \\
Range & & & \\
\hline
\end{tabular}

SD= standard deviation $\quad \mathbf{M W}=$ Mann Whitney $\quad \mathbf{S}=$ significant

$\mathbf{C R}=$ complete remission $\quad \mathbf{N R}=$ no remission 


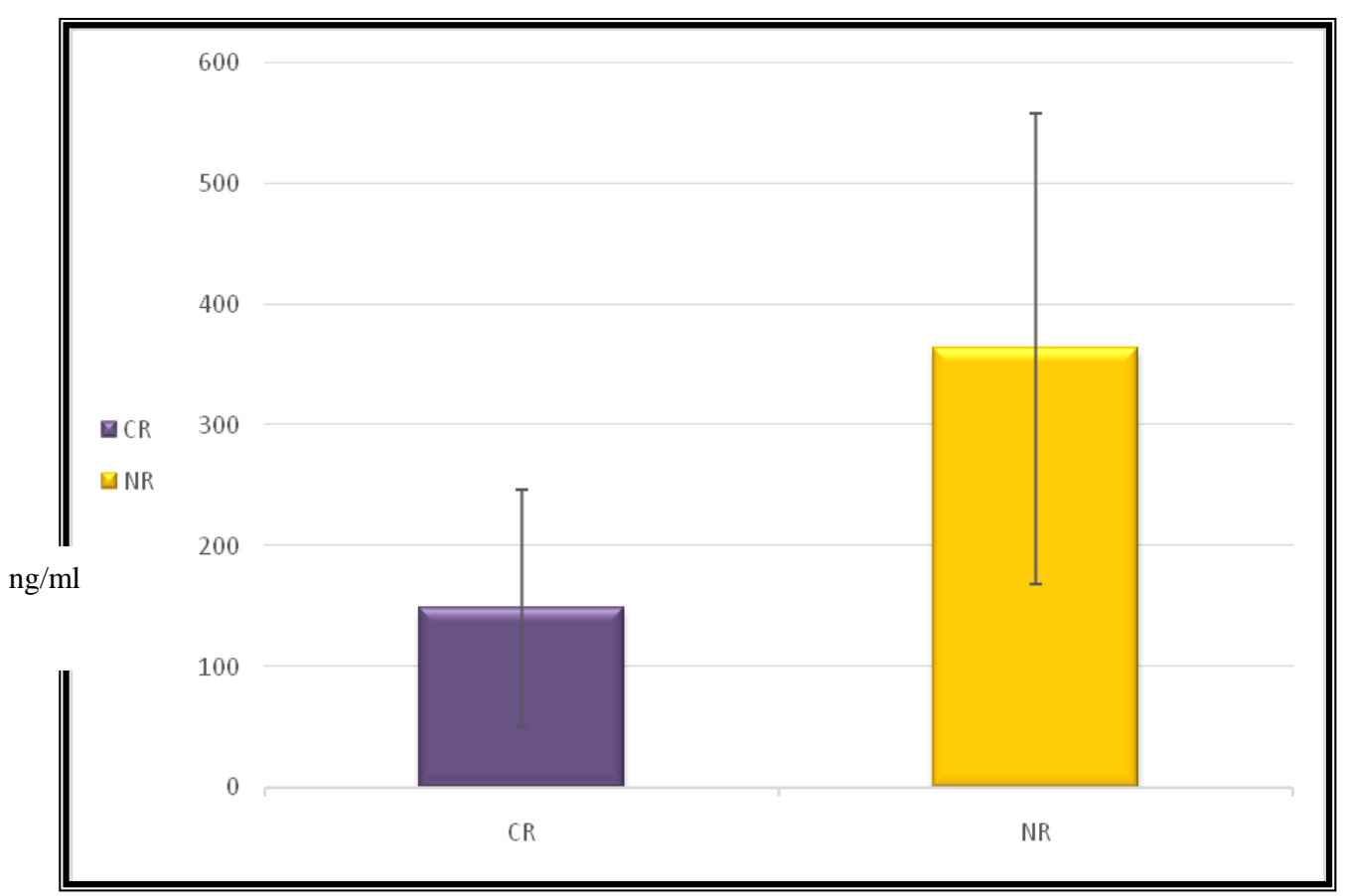

Fig. 7:- Comparison between CR and NR as regard YKL 40 level.

Table (5) and figure (7) show that there was a significant difference between CR and NR groups as regard YKL-40 level $(\mathrm{P}=0.004)$.

\section{Discussion:-}

Acute myeloid leukemia (AML) is a clonal malignant proliferation of myeloid blast cells in the marrow with impaired normal hematopoiesis. (20) It is the most common acute leukemia among adults and its incidence increases with age. (21)

Despite the advancement in treatment options for AML, its prognosis is very variable, ranging from survival of few days to cure. Many patients die either from complications of intensive chemotherapy, resistance to the current treatment options or they experience relapse after initial response to traditional chemotherapy. (22)

Moreover, there is still a need for simple reliable and easy measured factors which has an impact on the prognosis especially in area where modern technology is not usually available. So, in this study we measured the level of YKL-40 in serum of do novo AML patients to evaluate its role in prognosis and response to treatment. It was estimated at the onset of the disease and after 1 month of induction therapy. This cohort study was carried out in Clinical pathology and Medical Oncology \& Hematology Departments, Faculty of Medicine, Zagazig University Hospitals from February 2014 to February 2015 on 48 subjects classified into two groups: control group (24 normal individuals) and patient group (24 adult newly diagnosed AML patients).

In this study there was no significant difference between the control and patients as regards age and sex. This is in agreement with a study done by El Hefni et al., 2015 as both studies were done on adult AML patients. There was a slight female predominance in both studies but still with no significant difference with the control group. (23)

Among the newly diagnosed AML patients, fever was the most common clinical manifestation. It was found in $66.7 \%$ of patients, followed by organomegaly in $54.2 \%$, gum bleeding in $37.5 \%$, purpura in $29.2 \%$, Lymphadenopathy in $25 \%$ and CNS manifestation in 8.4\%of patients. This finding is in agreement with Weinblatt et al., 2004 who stated that fever is the most common initial clinical presentation. (24)

In the current study, there was a highly significant difference between the patients and control groups as regards TLC, hemoglobin concentration, platelets count and LDH. This was expected as these are directly attributable to the leukemic infiltration of bone marrow with resultant cytopenia (El Hefni et al., 2015). (23) 
Our studied patients were subdivided according to FAB classification into M1 (3 patients), M2 (12 patients), M3 (0 patient), M4 (5 patients) and M5 (4 patients). The majority of our patients were classified as M2, while no M3 subgroup was included in the study. According to national cancer institute, Brunning et al., 2001 stated that M2 is the most common morphologic type. (25)

As regard cytogenetic risk classification, the majority of the patients were included in the intermediate subgroup where the patients were subdivided into bad (16.7\%), intermediate $(58.3 \%)$, good (25\%) prognosis subgroups.

In this study, the levels of YKL-40 before induction therapy in patient group were significantly higher than those in control group. After induction therapy, it was noted that the level of YKL-40 was significantly decreased in patient group when compared with its level before treatment (98.5 versus $139 \mathrm{ng} / \mathrm{ml}$; respectively).

These were similar to the results of the studies performed by Bergmann et al., 2005 and El Hefni et al., 2015 who mentioned that YKL-40 plays a role in the malignant phenotype as a cellular survival factor. Furthermore, YKL-40 modulates vascular endothelial cell morphology by promoting the formation of branching tubules, indicating that YKL-40 has a role in angiogenesis by stimulating the migration and reorganization of vascular endothelial cells. YKL-40 also acts as a chemoattractant for endothelial cells, stimulates their migration and promotes the migration and adhesion of vascular smooth muscle cells. $(26,23)$

In this study, YKL-40 could predict response to treatment among AML patients at a cut-off $\geq 137 \mathrm{ng} / \mathrm{ml}$ with sensitivity 83.3\% and specificity 77.8\%.On the other hand, in the study done by Anil et al., 2013 the cut-off was 112 ng/ml where they used the $90^{\text {th }}$ percentile of YKL-40 values for the normal control group. (17)

In this study, when comparing patient groups with cut-off $\geq 137 \mathrm{ng} / \mathrm{ml}$ with that $<137 \mathrm{ng} / \mathrm{ml}$, we found that there was a significant difference between the two groups as regard platelets count and LDH. In agreement with our results Bergmann et al. 2005 found that there was a significant difference between high and low YKL-40 groups as regard LDH but no difference was observed in platelet count. This might be attributed to different sample size in both studies. (26)

Of note, no significant difference was found between the two groups as regard cytogenetic risk categories and FAB classification types. This goes hand in hand with the study done by Bergmann et al. 2005 who reported that the influence of cytogenetic was underestimated due to the small number of patients in both good and bad prognosis subgroups. (26)

After induction therapy, it was noted that CR rate was significantly lower in the patient group with YKL-40 level $\geq 137$ $\mathrm{ng} / \mathrm{ml}(54.5 \%)$ than that in those with YKL-40 level $<137 \mathrm{ng} / \mathrm{ml}(92.3 \%)$, indicating that high level of YKL-40 confers a poor outcome. This assumption can be further supported by our finding of high level of YKL-40 in NR group when compared with CR group (365ng/ml versus $127.5 \mathrm{ng} / \mathrm{ml}$; respectively). Same finding was reported by Bergmann et al., (2005) and El Hefni et al., (2015) who mentioned that YKL-40 play a role in proliferation and differentiation of malignant cells, protect the cells from undergoing apoptosis, stimulate angiogenesis and have an effect on extracellular tissue remodeling. All of these factors support its role to resist treatment and failure of remission. $(26,23)$

Moreover, Fahmy et al., $\mathbf{2 0 0 3}$ found that antiangiogenic intervention has achieved considerable effectiveness in the suppression of cancer growth and development which includes monoclonal antibodies against angiogenic factors. Faibish et al. 2011 also supported these results in experimental trial in mice where tube formation induced by YKL-40 was suppressed by a neutralizing anti-YKL-40 antibody. $(27,28)$

In this study, there was significant difference between the two groups (CR and NR) as regard CNS and lymphadenopathy. As their incidence was significantly more in those patients who did not achieve complete remission or got into relapse.

In addition, we found a significant correlation between YKL-40 and TLC, platelets count and LDH, which are considered prognostic factors. In a study done by Schmidt et al., 2005 on metastatic melanoma, they found that combination of YKL-40 and LDH as prognostic factors was able to divide patients into 3 prognostic groups that affect survival of patients and their elevation together was with the poorest prognosis group. (29)

Moreover, there was a significant relation between both CR and NR groups and cytogenetic risk categories which is considered the most prognostic factor identified at the time of diagnosis. On the other hand, Bergmann et al., (2005) and 
EL Hefni et al., (2015) did not find any relation with the cytogenetic risk categories. This might be attributed to selection criteria of studied groups. $(26,23)$

Taking together, high serum level of YKL-40 seems to add prognostic information in patients with AML. However, its predictive value is still unclear.

In the current study, DFS was shortened in patients with serum level of YKL-40 $\geq 137 \mathrm{ng} / \mathrm{ml}$ compared to the ones with level $<137 \mathrm{ng} / \mathrm{ml}$. Our results go hand in hand with that reported by Bergmann et al., (2005) who stated that high serum YKL-40 was related to short recurrence free interval and short overall survival. Moreover, Jensen et al., (2003) in breast cancer patients found that high serum YKL-40 was related to recurrence and less response to treatment. $(26,30)$

Our study shows that the high serum YKL-40 is a new independent prognostic biomarker in patients with AML. It may hold promise for developing novel therapeutic agent targeting YKL-40 that is over expressed in a broad range of human cancers.

\section{Conclusion:-}

It can be concluded that high serum level of YKL-40 was associated with bad response to treatment and confers poor outcome. Moreover, it could serve as valuable prognostic marker.

\section{References:-}

1. $\quad$ Russell NH. (1997): Biology of acute leukaemia. Lancet 1997. Jan 11; 349 (9045): 118-22.

2. Estey E H. (2001): Prognostic factors in acute myeloid leukemia. Leukemia, 15:670-2.

3. Kern W, Haferlach T, Schoch C (2003): Early blast clearance by remission induction therapy is a major independent prognostic factor for both achievement of complete remission and long-term outcome in acute myeloid leukemia: data from the German AML Cooperative Group (AMLCG) 1992 Trial. Blood; 101:64-70.

4. Cintin C., Johansen J.S., Christensen I. J., Price P.A., Sorensen S., and Nielsen H.J. (2002): High serum YKL-40 level after surgery for colorectal carcinoma is related to short survival. Cancer 95, 267-274.doi: 10.1002/cncr.10644.

5. Johansen J.S., Drivsholm L., Price P.A. and Christensen I.J. (2004): High serum YKL-40 level in patients with small cell lung cancer is related to early death. Lung Cancer, 46, 333-340.

6. De Ceuninck F., Gaufillier S., Bonnaud A., Sabatini M. and Lesur C (2001): YKL-40 (cartilage gp-39) induces proliferative events in cultured chondrocytes and synoviocytes and increases glycosaminogly can synthesis in chondrocytes. Biochemical \& Biophysical Research Communications 285: 926-931.

7. Recklies A.D., White C. and Ling H. (2002): The chitinase 3-like protein human cartilage glycoprotein 39 (HCgp39) stimulates proliferation of human connective-tissue cells and activates both extracellular signal-regulated kinase- and protein kinase B-mediated signalling pathways. Biochem J365: 119-126.

8. Varinder Jeet, Gregor Tevz, Melanie Lehman, Brett Hollier, and Colleen Nelson (2014): Elevated YKL40 is associated with advanced prostate cancer ( $\mathrm{PCa}$ ) and positively regulates invasion and migration of $\mathrm{PCa}$ cells. Endocr Relat Cancer. 2014 Oct; 21(5): 723-737.

9. Volck B., Price P.A., Johansen J.S., Sørensen O., Benfield T., Calafat J., Nielsen H.J. and Borregaard N. (1998): YKL-40, a mammalian member of the bacterial chitinase family, is a matrix protein of specific granules in human neutrophils. Proc Assoc Am Physicians 110:351-60.

10. Rehli M., Niller H.H., Ammon C., Langmann S., Schwarzfischer L., Andreesen R. and Krause S.W. (2003): Transcriptional regulation of CHI3L1, a marker gene for late stages of macrophage differentiation. J. Biol. Chem. 278, 44058-44067.

11. Cintin C, Johansen J S, Christensen I J, Price P A, Sørensen S, and Nielsen H J (1999): Serum YKL-40 and colorectal cancer. Br J Cancer. 1999 Mar; 79(9-10): 1494-1499.

12. Johansen J.S., Christensen I.J., Riisbro R., Greenall M., Han C., Price P.A., Smith K., Brunner N and Harris Al (2003): High serum YKL-40 levels in patients with primary breast cancer is related to short recurrence free survival. Breast Cancer Res Treat, 80:15-21.

13. Johansen, J.S., Roslind, A., Palle, C., Christensen, I.J., Nielsen, H.J., Price, P.A. and Nielsen, D. (2006): Mosgaard, B. Serum YKL-40 levels in patients with cervical cancer are elevated compared to patients with cervical intraepithelial neoplasia and healthy controls. ASCO Ann. Meet. Proc., 24, 267, Abstract 5047. 68. 
14. Roslind A., Johansen J.S., Christensen I.J., Kiss K., Balslev E., Nielsen D.L., Bentzen J., Price P.A. and Andersen, E. (2008): High serum levels of YKL-40 in patients with squamous cell carcinoma of the head and neck are associated with short survival. Int. J. Cancer, 122, 857-863.

15. Høgdall E.V., Ringsholt M., Høgdall C.K., Christensen I.J., Johansen J.S., Kjaer S.K., Blaakaer J., OstenfeldMøller L., Price P.A. and Christensen L.H. (2009): "YKL-40 tissue expression and plasma levels in patients with ovarian cancer". BMC Cancer 9: 8.

16. Mylin A.K., Rasmussen T., Johansen J.S., Knudsen L.M., Nørgaard P.H., Lenhoff S., Dahl I.M.S. and Johnsen H.E. (2006): Serum YKL-40 concentrations in newly diagnosed multiple myeloma patients and YKL-40 expression in malignant plasma cells. Eur. J. Hematol.77, 416-424.

17. Anil K. Hurmale, Sudheer K. Choudhary, Satish K. Bhaskar and Suresh K. Jatawa, (2013): Overexpression of chitinase like protein YKL-40 in leukemia patients Hurmale et al. J. BioSci. Biotech.2 (3): 215-220.

18. Kaplan E and Meier P (1958): Nonparametric estimation from incomplete observations. J Am Stat Assoc 1958; 53:457-481.

19. Martin Bland J and Douglas Altman G (2004): The logrank test. BMJ. 2004 May 1; 328(7447): 1073.

20. El Rassi F. and Arellano M. (2013): Update on Optimal Management of Acute Myeloid Leukemia. Clin Med Insights Oncol. 7: 181-197.

21. Sievers E.L., Larso R.A., Stadtmauer E.A., Estey E., Löwenberg B. and Dombret H. (2001): Efficacy and safety of gemtuzumab ozogamicin in patients with CD33-positive acute myeloid leukemia in first relapse. Journal of Clinical Oncology, 19:3244-3254.

22. Hwang K, Park CG and Jang S (2012): Flow cytometric quantification and immunophenotyping of leukemic stem cells in acute myeloid leukemia. Ann. Hematol.:91:1541-1546.

23. Ashraf M. El Hefni, Asmaa H E and Huda F. Ebian (2015): Prognostic Value of Human Chitinase 3-Like 1 in Adult Acute Myeloid Leukaemia.

24. Weinblatt M.E. (2004): Acute myelocytic leukaemia, http://www. emedicine. com.

25. Brunning RD, Matutes E and Flandrin G. (2001): Acute myeloid, leukaemias and myelodysplastic syndromes, therapy related. In: Jaffe ES, Harris NL, Stein H, et al., Pathology and Genetics of Tumors of Haematopoietic and Lymphoid Tissues. Lyon, France: IARC Press. World Health Organization Classification of Tumour (3): 89-91.

26. Bergmann O.J., Johansen J.S., Klausen T.W., Mylin A.K., Kristensen J.S., Kjeldsen E. and Johnsen H.E. (2005): High serum concentration of YKL-40 is associated with short survival in patients with acute myeloid leukemia. Clin.Cancer Res. 11, 8644-8652.

27. Fahmy R.G., Dass C.R., Sun L.Q., Chesterman C.N. and Khachigian L.M. (2003): Transcription factor Egr-1 supports F G F dependent angio Genesis during neovascularization and tumor growth. Nat Med 9:1026-1032.

28. Faibish M., Francescone R., Bentley B., Yan W., and Shao R. (2011): AYKL-40 neutralizing antibody blockstum orangiogenesis and progression: a potential therapeutic agentin cancers. Mol. Cancer Therap. 10,742-751.

29. Schmidt H., Johansen J.S., Gehl J., Geertsen P.F., Fode K. and von der Maase H. (2006): Elevated serum level of YKL-40 is an independent prognostic factor for poor survival in patients with metastatic melanoma. Cancer 106, 1130-1139.

30. Jensen B.V., Johansen J.S., and Price P.A. (2003): High levels of serum HER-2/neuandYKL-40 independently reflect aggressiveness of metastatic breast cancer. Clin.Cancer Res. 9, 4423-4434. 